\title{
SOURCES OF RULES FOR CONFLICT OF LAWS
}

\section{Eliotot E. Cheatham $\dagger$}

The division of the world into territorial units, as Pennsylvania and New York, the United States and France, creates for the lawyer a host of problems.

In the international sphere, where the United States of America is a member of the community of nations, two distinct but related sets of questions arise. One concerns controversies directly between nations, as, over boundaries, over ambassadors and their privileges, over armed forces. The body of law directed to them is Public International Law or, as it is usually styled, International Law. The second set of questions concerns cases between individuals engaged in private transactions, with relationships or contacts in two or more nations. So an oral agreement for the sale of goods made in England by a Frenchman and a Canadian to be performed in the United States may raise questions as to its validity or enforcement.

In intra-national matters two kinds of questions come up in the United States which correspond to those referred to in the international sphere. The first relates to cases between the states. They are settled by the Supreme Court of the United States under a law which it develops. The controversies between New York, New Jersey, and Pennsylvania as to the Delaware River, ${ }^{1}$ for example, are comparable to those over the Rhine and the Danube. The second set of questions concerns private transactions having elements in two or more states, as, an agreement made in New York by New Jersey residents and to be performed in Pennsylvania.

The controversies between individuals, not those primarily between nations or states, are the concern of this paper. Conflict of Laws or, as it is sometimes called, Private International Law, is the law principally directed to the transactions between individuals sketched above, whether inter- or intra-national. The common law of the states on the subject, however, may not be all important. The community of nations under International Law and the community of states of the Union under the Constitution, as well as the several states through their statutes, have sought to give directions or set limits in the disposition of at least some of the cases.

$\div$ A. B., 1907, University of Georgia ; LL. B., IgrI, Harvard University ; Professor of Law, Columbia University; editor of CASEs AND other MATERIALS on the LEgaL PROFESSION (I938); co-editor with Dowling and Goodrich of CASES AND OTHER MATERIALS ON CONFLICT OF LAWS (1936); author of various articles in legal periodicals.

I. See New Jersey v. New York, 283 U. S. 336, 342 (I93I). 
There are, consequently, three bodies of law which an American lawyer or judge may have to consider in dealing with these cases: International Law; Federal law, the law developed by the federal government and its various agencies; State law, the law developed by the states of the Union. The purpose of this Article is to consider very briefly the application of each of them to the major problems dealt with in Conflict of Laws. Those problems involve the jurisdiction of courts, the enforcement of foreign judgments, and the choice of the applicable law. In their solution do we draw only on state common law or must we consider as well International Law, Federal law, and state statutes?

\section{InTERnational Law}

On the relationship of International Law to Conflict of Laws, extreme and contrasted views have been expressed. ${ }^{2}$

A duty under International Law on the courts of a nation to apply the appropriate rules of Conflict of Laws has been asserted. So Professor Stowell writes:

"The system of laws, known as conflict of laws or private international law, is administered by national courts and is a part of the national system of administration of justice. Nevertheless, in the discharge of this duty the national courts fulfill an international function analogous to that fulfilled by prize courts, which are national courts. . . . The rule applied is, it is true, a part of the national system of law, but the obligation to apply the rule identical with that of the foreign jurisdiction is none the less an international law obligation which rests upon the state." 3

The contrary position has been thus outlined:

"Anglo-American writers and the nationalists in general are in the habit of asserting that international law leaves the different nations absolutely free in regard to the adoption of their rules of the conflict of laws, and that they may, if they desire, adjudicate all cases in accordance with their own rules of internal laws." 4

2. The relation of international law to national law generally is not considered in this Article. See Dickinson, Changing Concepts and the Doctrine of Incorporation (1932) 26 AM. J. INT. L. 239; Potter, Relative Authority of International Law and National Law in the United States (I925) I9 AMr. J. INT. L. 315; Wright, Interitational Law in its Relation to Constitutional Law (1923) I7 AM. J. INT. L. 234. For collections of authorities on the subject, see DICKINSON, CASES AND READINGS ON THE LAW of Natrons (I929) 39 et seq.; SCOTt AND JaEger, CASES on International. LAW (1937) 2I-29.

3. Stowel., Internatronal Law (I93I) 299-300. See also I Lorimer, InstiTUtes of the LAW of Nations (1883) 350 et seq. Cf. J. G. Starke, The Relation Between Private and Public International Law (1936) 52 L. Q. REv. 395. For a careful analysis by a writer supporting an international obligation as to a part of the field, see Farrelly, The Basis of Private Intcrnational Law (I893) 4 L. Q. REv. 242.

4. Lorenzen, The Theory of Qualifications and the Conflict of Laws (1920) 20 CoL. L. REv. 247, 269. See also Beckett, What is Private International Law? (1926) 7 BRIT. Y. B. INT. L. 73 . 
Such a diversity of views is apt to spring from the use of the same term with different meanings, and "International Law" has been given various meanings. Some of these special meanings, ${ }^{5}$ if not erroneous, at least make International Law irrelevant to the purpose of this article, which as indicated above is to consider only whether a lawyer or a judge in dealing with a Conflict of Laws case should take it into account. For discussion here the question is subdivided: First, are national courts controlled or guided in these cases by International Law? Second, do proceedings through diplomatic channels or before international tribunals offer relief for asserted erroneous decisions of these cases by national courts?

I. Are national courts given guidance in Conflict of Laws cases by International Law?

As to a part of the field of jurisdiction of national courts, the principles of International Law undoubtedly apply. In determining whether a nation or its representatives may be sued, and whether its property may be seized under judicial process, the courts concede the immunities from jurisdiction indicated by International Law. ${ }^{6}$ Further, in determining the extent of national jurisdiction over marginal waters and over American vessels in foreign waters, the limits suggested by International Law will ordinarily be followed. ${ }^{7}$ Where a statute is not specific on the matter its scope of application will be determined in accordance with International Law. In United States $v$. Flores, ${ }^{8}$ an American citizen was indicted in a United States District

5. The widespread concurrence or similarity of some conflict of laws rules has been suggested as a reason for calling Conflict of Laws a part of International Law. The first development of the subject occurred with the revival of the study of Roman law in the Italian universities, when there was one common intellectual language and the universities were truly cosmopolitan. The effects of this origin long persisted. In more recent times this concurrence has been favored by a freer use of comparative law by writers in the field, notably Story, and even more because similar conditions have produced similar or identical legal results. This coincidence, however, is no proof that the law applied is International Law in the usually accepted sense.

When the coincidence is brought about by treaty, there is greater reason for calling the rule a part of International Law; though the writer believes it more helpful to consider treaties here as a part of national law and they will be discussed below under federal law.

At times international tribunals have to consider Conflict of Laws problems, but the limited nature of these cases has been pointed out. Niboyet, Le Rôle de la Justice International en Droit International Privé: Conflit des Lois, 40 ACADÉmIE DE DRoIT INTERNational, RECUEIL DES CoURS (1932) 157.

The views of leading European exponents of an international system of Conflict of Laws are set out and discussed in III BEALE, Conflict of LAwS (I935) I948-I962.

6. For collections of authorities on jurisdictional immunities, see DickINson, op. cit. supra note 2 at c. 6 ; Hudson, Cases and Other Materials on Internatronal LAW (2d ed. I936) 504-538; SCOTT AND JAEGER, op. cit. supra note 2 at c. 6 . See also Competence of Courts in Regard to Foreign States, Research in International Law, (I932). This problem of competence of courts over foreign nations is not within the field usually assigned to Conflict of Laws.

7. Jessup, The Law of Territorial Waters and Maritime Jurisdiction (ig27). 8. 289 U. S. I37 (I933). 
Court for the murder of another American citizen committed on an American vessel in the territorial waters of the Belgian Congo. The prosecution was based on a United States statute which extended part of the Criminal Code to offenses "committed within the admiralty and maritime jurisdiction of the United States and out of the jurisdiction of any particular state, on board any vessel belonging" to one of its nationals. In holding the statute did apply, the court said:

". . . it is the duty of the courts of the United States to apply to offenses committed by its citizens on vessels flying its flag, its own statutes, interpreted in the light of recognized principles of international law, . . ." 9

Beyond these and kindred matters, ${ }^{10}$ International Law as it may bear on Conflict of Laws is much less specific.

There are those, however, who see the guide through the mazes of Conflict of Laws, if not in the developed rules, then in the basic conceptions of International Law, especially in the conception of sovereignty. The most influential of these is Story. In his treatise on Conflict of Laws, he states and discusses three "general maxims or axioms which constitute the basis upon which all reasoning on the subject must necessarily rest". ${ }^{11}$ The fundamental one, from which the other two are derived, is "Territorial Sovereignty of Every Nation" and is thus stated:

"The first and most general maxim or proposition is . . that every nation possesses an exclusive soverignty and jurisdiction within its own territory." 12

This maxim or proposition is merely a reflection of the present political fact, out of which arise difficulties dealt with by Conflict of Laws. ${ }^{13}$ It indicates those difficulties, but does not itself solve them. Here, as everywhere in the law, constant consideration must be given to the conditions creating the problems to be dealt with. But a mere indication of the condition, given in maxim form and expressed in general terms, cannot of itself give the result or the rule to be used, save in the simplest case.

9. Id. at $\mathrm{I} 59$.

Io. For other matters, see Crapo v. Kelly, I6 Wall. 6ro (U. S. I873) ; Dicey, ConFLICT of Laws (5th ed. I932) 653. See also VAN PraAg, JuRispiction ET DroIt INternational PUblic (1915).

II. StORy, CONFLICT OF LAws (8th ed. I883) 2r-39. For a critical analysis of Story's maxims, see Cook, Jurisdiction of Sovereign States and the Conflict of Lazes (193I) 3I COL. L. REv. 368.

I2. STORY, op. cit. silpra note II at 2I.

I3. Dunn, Intemational Law and Private Property Rights (1928) 28 CoL. L. Rev. I66, I7I-172. 
It would be unwise to seek to deduce the rules for this complex subject from a single factor of conception, however fundamental; for the elements which go to shape Conflict of Laws, like other parts of the law, are numerous. ${ }^{14}$ Sovereignty is a particularly unfortunate single basis of reasoning, for not only is the concept an elusive one, but there are states or legal units of varying degrees of independence ${ }^{15}$ and the whole notion of complete territorial sovereignty is under attack on various grounds from the pluralists on the one side to the internationalists on the other. Moreover, long before the present doctrine of sovereignty had been stated, there existed states and nations with diverse laws and courts, notably the Italian city state of the later Middle Ages. Conflict problems and Conflict solutions did not await Bodin or his successors.

2. May redress be had through international channels for errors in Conflict of Lazes?

The second question as to International Law is: May relief be had through the usual international machinery, as diplomatic channels or international tribunals, for asserted errors by national courts in Conflict of Laws cases?

A nation may, and not infrequently does, use measures to secure redress for gross injustices done to its citizens abroad. ${ }^{16}$ The fact that the injustice was perpetrated by a court, whose decision is final in the national sphere, is no bar. Indeed, the very basis of the international claim is the validity for municipal purposes of the action of the national court and the consequent injury to the citizens of the complaining nation. The matter was well stated in Gray $v$. United States. ${ }^{17}$ A federal statute empowered the Court of Claims to entertain claims based on alleged violations of international law by France during the wars of the French Revolution, in seizing by its warships and condemning in its prize courts ships owned by citizens of the United States, a neutral nation. The point was made against the claims that the condemnation of the ships by the French prize courts was effective. In rejecting the objection, Davis, J. said :

"The defendants say, further, the condemnation cannot be illegal because made by a prize court having jurisdiction, and the deci-

I4. Restatement, Conflict of Laws (1934) $\$ 5$, comment $b$; Beale, Social Justice and Business Costs (I936) 49 HARv. L. REv. 593, 607-609; Cook, The Logical and Legal Bases of the Conflict of Laws (I924) 33 Y $\mathrm{ALE}$ L. J. 457, 486-488.

I5. See Georgia v. Tennessee Copper Co., 206 U. S. 230, 237-240 (1907); De Simone v. Transportes Maritimos Do Estado, 200 App. Div. 82, 84, I92 N. Y. Supp. 8I5, 8i7 (ig22) ; MeILI, InTernational Civil aNd Commercial Law (Kuhn's translation, I905) 123.

i6. Borchard, Diplomatic Protection of Citizens Abroad (igi5).

I7. 21 Ct. Cl. 340 (I886). 
sions of such courts are final and binding. This proposition is of course admitted so far as the res is concerned; the decision of the court, as to that, is undoubtedly final, and vests good title in the purchaser at the sale; not so as to the diplomatic claim, for that claim has its very foundation in the judicial decision, and its validity depends upon the justice of the court's proceedings and conclusion. . . The diplomatic claim, therefore, is based not more upon the original wrong upon which the court decided than upon the action and conclusion of the court itself, and, diplomatically speaking, there is no claim until the courts have decided. That decision, then, is not only not final, but, on the contrary, is the beginning, the very corner-stone, of the international controversy. . . " 18

Among the injuries generally recognized as a basis of international complaint, is a class of cases entitled "Denial of Justice to Aliens". ${ }^{19}$ Do errors of Conflict of Laws create such a basis of complaint, whether the error be as to jurisdiction of courts, enforcement of judgments, or choice of law?

With respect to jurisdiction of courts over private individuals, the provisions of the various systems of law vary widely. ${ }^{20}$ Even a serious deviation by the court of one nation from the jurisdictional rules of another nation in a wholly private case (leaving aside cases against a nation or its representatives) seems to constitute no ground of international protest; though it may be a reason for declining to enforce the judgment. In Schisby $v$. Westenholz, ${ }^{21}$ where a French court had entertained a suit by a Dane resident in France against an absent foreigner, the English court refused to enforce the judgment. Westlake, after commenting on the "exorbitant character" of such an exercise of jurisdiction, stated it "would not be considered to present a case important enough for direct intervention". ${ }^{22}$ If, however, the court of a nation with no relationship to the parties or the transaction were to entertain a suit against an absent foreigner and were to enforce the resulting judgment against his property later brought in, the opinion may be hazarded the proceeding would fall short of the minimum standard of "international procedural justice". And certainly, if there is a refusal

I8. Id. at 402. See also EAgLETON, ResponsibILITY of STATES IN INTERNational LAW (I928) § 22; I HYDE, INTERNATIONAL LAW (I922) II-I3. The United States has on many occasions submitted to international tribunals controversies which had already been decided by the Supreme Court. See Root, The Relation between International Tribunals of Arbitration and the Jurisdiction of National Courts (1909) 3 AM. J. INT. L. 529, 535 .

I9. For an extensive discussion of the subject, see FreEman, The International Responsibility OF STATES FOR DeNIAL OF Justice (1938). For a discussion of the indefiniteness of the term, see Lissitzyn, The Meaning of the Term Denial of Justice in International Law (1936) 30 Axr. J. INT. L. 632.

20. See Westrake, PrIVATE International Law (Bentwich ed. 1925) cc. 9, Io. 2r. L. R. 6 Q. B. $155(1870)$.

22. Westlake, International LaW (2d ed. I9I0) 249. 
to an alien of all access to a court for the redress of a wrong done to him, there may be grounds for international complaint. ${ }^{23}$

As to foreign judgments, the methods and conditions of enforcement vary widely, ${ }^{24}$ with no basis of international complaint. If, however, the enforcement of a foreign judgment is entirely prevented by devious actions of local courts, this has been held ground for holding the offending nation responsible. ${ }^{25}$

As to the choice of law, the situation has been well stated by Professor Baty:

"It is worth remarking that to some small and very indefinite extent every country is, indeed, bound to recognize foreign law. For it is an established principle of 'Public' International Law (the rules binding on States), that the persons and property of foreigners must be (to a certain indefinite extent) respected. And if by declining to take any notice of foreign law, one country were to deny that the property of a foreigner was his property at all, it might conceivably be that a genuine wrong would be done to the foreign state to which he belonged. To that extent, Private International Law coincides with Public International Law. But it is a very small extent. For each State is perfectly free to adopt whatever rules for the choice of law it likes, provided that they do not outrage the general feeling of humanity. . . . indeed, there is no need that the rule should be one of the well-recognized ones; it is sufficient that it is not arbitrary or outrageous." ${ }^{26}$

Aside from criminal prosecutions, ${ }^{27}$ the cases known to the author in which there has been international complaint are very few. In one, involving the validity of the will of a British subject, the British Foreign Office complained because a decision upholding the validity of the will by a court of England, the domicil, had not been accepted by the courts of Peru as to the disposition of movables in Peru. ${ }^{28}$ In two other cases, involving the validity of marriage, the American State Department submitted suggestions to the authorities of $M$ Mexico ${ }^{29}$ and

23. FreEMAN, op. cit. supra note ig at c. 9 .

24. Lorenzen, The Enforcement of American Judgments Abroad (I9Ig) 29 Y YLE L. J. I88; Wigmore, The Execution of Foreign Judgments: $A$ Study in the International Assimilation of Private Law (I926) 21 ILL. L. REv. I.

25. FREEMAN, op. cit. sipra note I9 at c. I4.

26. The Private Intemational Law of Japan (1939) Monumenta NIPPonICA, Vol. II, No. 2, 54, 55. See also I Westlake, International Law (2d ed. I9io) 248250; DUNN, op. cit. supra note I3 at I75; FREEMAN, op. cit. supra note 19 at c. I7; I Niboyet, Traité de Droit International Privé (i938) 67, 68.

27. Cf. Cutting's Case, II Moore, International Law Digest (I906) 228; The Steamship "Lotus", Permanent Court of International Justice Publications (Series A, No. I0, I927).

28. Fontes JURis Gentium, Series B, Digest of the Diplomatic Correspondence of the European States I856-187I (Vol. I, I932) II9. For the information on the complaints referred to in this note and the two following, the writer is indebted to Mr. James Simsarian, of the New York Bar.

29. Mr. Webster, Secretary of State, to Mr. Letcher, Minister to Mexico (1842), II Moore, International Law Digest (Igo6) 484. 
Switzerland ${ }^{30}$ that the appropriate law to use was the law of the place of marriage. It seems to have been recognized in the American correspondence, however, that if a contrary view were taken, there would be no basis for further complaint.

\section{FEDERAL LAw}

Our American experience reveals that under a federal system there must be at least three sets of powers in the national government. First, there must be a centralization of control over foreign relations, over the field of Public International Law. In the United States there is this centralization, which makes the nation a unit for foreign affairs and to that extent eliminates federalism. Second, the nation must be able, without the intervention of the states, to make a uniform national law on certain matters. This power over some areas does reside in our central government. To the extent the central government exercises the power, the nation is a unit for internal purposes and federalism is abrogated.

The third set of powers, vested in one of the divisions of the national government, enables it to compel each state to give to the other states and to the citizens of the other states a minimum of fair treatment, without discrimination. Our Constitution contains provisions designed to this end. Some of the provisions set a uniform minimum throughout the nation. Others let each state set the minimum for its own citizens and then require that this minimum be accorded to the citizens of other states.

This Article will not attempt even to enumerate all of the powers of our national government over international and interstate matters. Its only purpose is to sketch the bearing of such powers on the problems usually dealt with in Conflict of Laws. The matter will be treated in connection with each of the types of federal law in question: ( $x$ ) The Constitution of the United States, (2) Federal Statutes, (3) Treaties, (4) Federal Common Law.

\section{The Constitution of the United States}

It has long been settled that the Constitution does exert controlling effect over two of the general questions of Conflict of Laws, jurisdiction of courts and enforcement of judgments of courts of sister states.

The Constitution has often been invoked in attacks on judicial proceedings when the state or the court lacked jurisdiction, whether the proceedings were in personam against individuals or corporations, or as

30. Mr. Seward, Secretary of State, to Mr. Harrington, Minister to Switzerland (1868), Papers Relating to Foreign Affairs, Part II (I869) I92-197. 
to property, or as to status. The provision of the Constitution relied on is the due process clause of the Fourteenth Amendment. Pennoyer $v . N e f^{31}$ is the leading case. The development of these ideas of judicial jurisdiction may be followed in the treatises on Conflict of Laws. ${ }^{32}$

As to enforcement and effect of judgments of sister states, the full faith and credit clause of the Constitution and the Act of Congress pursuant to it are well known. Their operation is discussed in the same treatises.

With respect to control of choice of law, however, the place of the Constitution has not been so obvious. The purpose proclaimed in the Preamble to the Constitution, "to form a more perfect Union", requires that as to some matters the laws of the states, with their diversities, be eliminated and that there be a single national law. To the extent that there is such a law established by the Constitution the intranational problems of choice of law created by these old diversities disappear. For the most part, however, the Constitution did not destroy the autonomy of the states, and the variety of state laws within the nation has made necessary the resolution of the resulting conflicts. Indeed, in no other great nation is the problem of conflicts so extensive or so important as with us. Does the Constitution have any effect in their resolution?

In support of the view that the Constitution has no effect, there is frequently quoted a passage from Kryger $v$. Wilson, ${ }^{33}$ decided in I9I6, in which the substantial question before the state court had been, which law governed the power of a vendor of North Dakota land to terminate the rights of a defaulting vendee under a Minnesota contract. Justice Brandeis, in declining to review the state court's answer, said:

"The most that the plaintiff in error can say is that the state court made a mistaken application of doctrines of the conflict of laws in deciding that the cancellation of a land contract is governed by the law of the situs instead of the place of making and performance. But that, being purely a question of local common law, is a matter with which this court is not concerned." ${ }^{34}$

These somewhat cryptic words cannot now be deemed as denying the operation of the Constitution in the whole field of choice of law. Indeed, the language of some provisions of the Constitution, as, the full faith and credit clause, seems specifically directed to these matters.

3I. 95 U. S. 7 I4 (1877). It should be observed the state court proceedings under attack in this case arose prior to the ratification of the Fourteenth Amendment.

32. I Beale, Conflict of Laws (I935) c. 4; Goodrich, Conflict of Laws (2d ed. I938) c. 4 ; StUMBerg, Conflict of Laws (I937) c. 4.

33. 242 U. S. I7I (1916).

34. Id. at 176 . 
And the Court has, through opinions by the same justice and by other justices, asserted the control of the Constitution over the choice of law in some torts, workmen's compensation, and contracts cases.

The practical question now is, granting there is some Constitutional control, in what situations will it be exercised and how rigid is the control? Several writers have dealt with this question, ${ }^{35}$ which cannot be treated at length here. An indication of the criterion of control may be given by quotations from two recent opinions of the Court. In Hartford Accident \& Indemnity Co. v. Delta \& Pine Land Co., ${ }^{36}$ there was involved the application of a Mississippi statute to a contract made and to be performed (as the Court found) in Tennessee. Justice Roberts in holding this use of the statute was a violation of the due process clause said:

"A legislative policy which attempts to draw to the state of the forum control over the obligations of contracts elsewhere validly consummated and to convert them for all purposes into contracts of the forum, regardless of the relative importance of the interests of the forum as contrasted with those created at the place of the contract, conflicts with the guaranties of the Fourteenth Amendment." 37

And in Alaska Packers Association v. Industrial Accident Commission of California, ${ }^{38}$ involving the application of the California workmen's compensation act to an injury suffered in Alaska, Justice Stone described the test of application of the full faith and credit clause:

"In the case of statutes, the extra-state effect of which Congress has not prescribed, where the policy of one state statute comes into conflict with that of another, the necessity of some accommodation of the conflicting interests of the two states is still more apparent. . . . the conflict is to be resolved, not by giving automatic effect to the full faith and credit clause, compelling the courts of each state to subordinate its own statutes to those of the other, but by appraising the governmental interest of each jurisdiction, and turning the scale of decision according to their weight." 39

35. See Dodd, The Power of the Supreme Court to Review State Decisions in the Field of Conflict of Lazws (1926) $39 \mathrm{HARv}$. L. REv. 533; Hilpert and Cooley, The Federal Constitution and the Choice of Law (I939) 25 WASH. L. Q. 27 ; Langmaid, The Full Faith and Credit Required for Public Acts (1929) 24 ILL. L. Rev. 383 ; Ross, Has the Conflict of Laws Become a Branch of Consitutional Law? (I93I) I5 MiNN. L. Rev. I6I, "Full Faith and Credit" in a Federal System (1936) 20 MINN. L. REv. I40; Smith, The Constitution and the Conflict of Laws (1939) 27 GEo. L. J. 536.

36. 292 U. S. 143 (I934).

37. $I d$. at $\mathrm{r} 50$.

38. 294 U. S. 532 (1935).

39. Id. at 547 . 


\section{Federal Statutes}

The Congress is entrusted by the Constitution with power of control over much of the interstate and international field. The control when exercised may substitute a single national law for the various state laws. The Federal Bankruptcy Act, supplanting the state bankruptcy laws, ended the old troublesome interstate Conflicts problems of priorities and discharge in bankruptcy. The most familiar examples of this control are under the interstate commerce power. Two closely parallel cases illustrate the effect of the exercise of the power. In Western Union Telegraph Co. v. Brown a telegraph message was received for transmission by the company in South Carolina, addressed to the plaintiff in Washington, D. C. Through the negligence of the company's servants in Washington the message was never delivered, and the failure caused the plaintiff to miss attending her sister's funeral in South Carolina. The law of the District of Columbia gave no cause of action for mental anguish but the South Carolina law did give it; and the plaintiff, suing in the South Carolina courts, recovered damages for missing the funeral. Since the message had been sent in 1908, two years prior to any legislation by Congress on the subject, the Supreme Court of South Carolina treated the case as an ordinary Conflict of Laws case, and held the South Carolina law governed. ${ }^{40}$ The Supreme Court of the United States, however, reversed the judgment, ${ }^{41}$ because it was a violation of the Constitution to use the South Carolina law. Though the opinion of the Court is very brief, the grounds apparently were two: first, as liability in tort is governed by the law of the place of the tort, it was a violation of the Constitution to fail to use the law of the District of Columbia where the tort occurred; second, the use of South Carolina law in so grossly erroneous a way was an inadmissible interference with interstate commerce. Some years later in Western Union Telegraph Co. v. Boegli, ${ }^{42}$ a message was handed to the telegraph company in Illinois for transmission to a point in Indiana, but through negligence of the company's representatives in Indiana it was delivered so late that the purpose of the message failed. The company was sued for a penalty imposed by the law of Indiana, the place of the negligence, for failure to deliver the telegram, and the Indiana courts gave recovery. The whole transaction took place subsequent to the Mann-Elkins Act of $1910^{43}$ regulating interstate telegraph companies, which was deemed to impose the federal law in the field. The

40. Brown v. Western Union Tel. Co., 85 S. C. 495,67 S. E. I46 (1910).

4I. Western Union Telegraph Co. v. Brown, 234 U. S. 542 (I9I4).

42. $25 \mathrm{I}$ U. S. 315 (1920).

43. 36 Stat. 539, 544 (1910), 49 U. S. C. A. § I (ic, 1937). 
State court's decision was accordingly reversed, not because the court used the law of the wrong State, but because the federal law supplanted the law of all the States. The court said:

"the provisions of the statute bringing telegraph companies under the Act to Regulate Commerce, as well as placing them under the administrative control of the Interstate Commerce Commission, so clearly establish the purpose of Congress to subject such companies to a uniform national rule as to cause it to be certain that there was no room thereafter for the exercise by the several states of power to regulate, by penalizing the negligent failure to deliver promptly an interstate telegram, and that the court below erred, therefore, in imposing the penalty fixed by the state statute." ${ }^{44}$

A federal statute promulgating a single national rule for all transactions of a particular type arising anywhere in the United States may, in the attempt to avoid the old difficulties of Conflict of Laws between the states, introduce an even more troublesome problem of demarcation between the proper spheres of federal and state laws. The Federal Employers Liability Act has substituted for the Conflict of Laws problem the manifold intricacies of determining whether the accident occurred in interstate commerce, so that the Federal Act applies. In consequence it has been advocated that the whole subject be returned to the states or that a federal compensation act be adopted so sweeping as to include the whole field and to eliminate all the old doubtful jurisdiction problems. ${ }^{45}$

A wholly different question as to Federal statutes has been suggested. In fields where the diversity of State laws continues, can Congress prescribe the Conflict of Laws rule to be used in choosing the governing law? If the subject of regulation is, like interstate commerce, one which Congress could have taken over entirely, it would seem that Congress could exercise the lesser power of merely designating the state law to be used. Even if the subject is not one which Congress could have taken over completely, it may nevertheless be that it has the lesser power. The full faith and credit clause, it will be remembered, includes within its scope "public acts" of the states and gives authority to Congress to deal with them, in these words:

"And the Congress may by General Laws prescribe the Manner in which such Acts, Records and Proceedings shall be proved, and the Effect thereof." 46

44. Western Union Telegraph Co. v. Boegli, 25I U. S. 3I5, 3 I6.

45. Gellhorn, Federal Workmen's Compensation for Transportation Employees (I934) 43 YALE L. J. g06; Schoene and Watson, Workmen's Compensation on Interstate Railways (I934) 47 HARv. L. REv. 389.

46. U. S. Const. Art. IV, § I. 
The scope of this power has been commented on by Justice Stone :

"The constitutional provision giving Congress power to prescribe the effect to be given to acts, records and proceedings would have been quite unnecessary had it not been intended that Congress should have a latitude broader than that given the courts by the full faith and credit clause alone." 47

Moreover, the Fourteenth Amendment, the due process clause of which as seen above has some effect on the choice of law in Conflict of Laws, contains the enabling clause:

"The Congress shall have power to enforce, by appropriate legislation, the provisions of this article."

It has been suggested that under this clause Congress might exercise important control over the whole field of choice of law. ${ }^{48}$

\section{Treaties}

In a well-known passage in Hilton $v$. Guyot ${ }^{49} \mathrm{Mr}$. Justice Gray, discussing the sonrces of the rules of International Law and Private International Law, said:

"The most certain guide, no doubt, for the decision of such questions is a treaty or statute of this country."

There was for long a doubt whether the treaty power extended over the whole field of Conflict of Laws. For example, in I928 at the Sixth International Conference of American Nations meeting in Havana there was proposed a Code of Private International Law drafted by Dr. Bustamente. The delegation of the United States, thus expressed its attitude toward the code:

"The Delegation of the United States of America regrets very much that it is unable at the present time to approve the Code of Dr. Bustamente, as in view of the Constitution of the United States of America, the relations among the States members of the Union and the powers and functions of the Federal Government, it finds it very difficult to do so." 50

These doubts have been completely dispelled, it is believed, by a series of recent cases. ion).

47. See Yarborough v. Yarborough, 290 U. S. 202, 2I5 (1933) (dissenting opin-

48. Corwin, The "Full Faith and Credit" Clause (I933) 8I U. OF PA. L. Rev. 37I; Cook, The Pozvers of Congress under the Full Faith and Credit Clause (I9I9) 28 Y YLE I. J. $42 \mathrm{I}$.

49. I59 U. S. II3, I63 (I895).

50. Report of the Delegates of the United States of America to the Sixth International Conference of American States, pp. I67-168 (1928). Mr. Hughes, the chairman of the American delegation, later set out the reasons actuating the delegates. 23 Proceedings Amer. Soc. of Int. Law (I929) 194-Ig6. 
The first one, Santovincenzo $v$. Egan, ${ }^{51}$ deserves a full statement. An Italian national, who had long made his home in New York, died intestate without heirs or next of $\mathrm{kin}$, and his small estate consisting of personal property was administered on by the public administrator. Under the statutes of New York, the net estate of one dying intestate and without heirs or next of kin would go ultimately to the State of New York. The consul general of Italy, however, claimed the estate for the Kingdom of Italy, under the most favored nation clause in the Convention between Italy and the United States, which it was asserted incorporated the terms of a treaty between Persia and the United States, giving such a right to the foreign nation. The able surrogate before whom the case first came thought it clear the treaty did not override the statute, ${ }^{52}$ and referred to an earlier case in which Judge Cardozo had quoted and intimated doubts as to the scope of the treatymaking power. The appellate courts in New York believed the matter obvious, so the Appellate Division ${ }^{53}$ without opinion unanimously affirmed the surrogate, and leave to appeal to the Court of Appeals was denied. The case was then carried to the United States Supreme Court, which unanimously reversed the New York courts. It will be observed that the contest was between the Kingdom of Italy and the State of New York over property in New York and the treaty nullified the application of statutory escheat, one of the fundamental powers of the state of New York. Chief Justice Hughes stated the broad control of the treaty-making power over Conflict of Laws:

"The treaty-making power is broad enough to cover all subjects that properly pertain to our foreign relations, and agreement with respect to the rights and privileges of citizens of the United States in foreign countries, and of the nationals of such countries within the United States, and the disposition of the property of aliens dying within the territory of the respective parties, is within the scope of that power, and any conflicting law of the State must yield." 54

Supporting the same conclusion is United States $v$. Belmont, ${ }^{55}$ which involved the effect of a compact entered into by the President on behalf of the United States at the time of the recognition of the Soviet Government. Under the terms of the compact, the Russian government assigned to this government all claims it had against American nationals, including the claims held by Russian corporations whose

5I. 284 U. S. 30 (I93I).

52. In re Cominico's Estate, 135 Misc. 733, 240 N. Y. Supp. 69I (Surr. Ct. 1929).

53. 229 App. Div. 862, 243 N. Y. Supp. 8I4 (Ist Dep't I930).

54. Santovicenzo v. Egan, 284 U. S. 30, 40 (I93I).

55. 301 U. S. 324 (I937). 
assets had been taken over by the Russian government. When a suit was instituted in the Federal court against a private banker in New York to recover a sum deposited by a Russian corporation, the lower courts denied recovery, principally on the ground the Russian decrees of confiscation were against the public policy of New York. The Supreme Court, in reversing the lower courts, said:

"Governmental power over internal affairs is distributed between the national government and the several states. Governmental power over external affairs is not distributed, but is vested exclusively in the national government. . . complete power over international affairs is in the national government and is not and cannot be subject to any curtailment or interference on the part of the several states. Compare United States v. Curtiss-Wright Export Corp., 299 U. S. 304, 3I6, et seq. In respect of all international negotiations and compacts and in respect of our foreign relations generally, state lines disappear. As to such purposes the State of New York does not exist." 56

These cases establish that the United States, like other nations, has the power by treaty to establish the rules of Private International Law. And if a right under a treaty is ignored by the courts of a state, the injured party may secure relief from the Supreme Court, or in an appropriate case, through international channels. The treaties regulating such problems are numerous, but it is not the purpose of this article to collect these treaty provisions.

Two other types of treaties important here have been suggested. One is a treaty which would create a uniform rule among the nations parties to the treaty, as to all international transactions dealt with. ${ }^{57} \mathrm{~A}$ recent example concerns carriage of goods by sea. The international convention for the unification of certain rules relating to bills of lading, was ratified by the Senate with some reservations. ${ }^{58}$ Substantially, the same provisions were also included in an Act of Congress, the Carriage of Goods by Sea Act. ${ }^{59}$

Still another type of treaty discussed would create a uniform law, not merely as to international transactions but as to internal or local transactions as well, as a means of achieving uniformity and preventing conflicts. No such treaty has been negotiated, it is believed. ${ }^{60}$ (1930)

56. Id. at 328. See also Todok v. Union State Bank of Harvard, 28I U. S. 449 Rev. 543

57. See Rabel, A Draft of an Intemational Law of Sales (I938) 5 U. oF CHr. L.

58. 5I STAT. 233 (1937).

59. 49 STAт. I207, c. 229 (1936), 46 U. S. C. A. §1300 (Supp. 1940).

6o. See Hudson and Feller, The International Unification of Laws Concerning Bills of Exchange (193I) 44 HARv. L. REv. 333; Jitta, The Development of Private International Laze through Conventions (1920) 29 YALE L. J. 497, 502; Note (1937) 37 CoL. L. REV. I36I. 
The regulation by the federal government of international private matters has so far been effected either under the treaty-making power or by an Act of Congress rested on the admiralty or foreign commerce clauses of the Constitution. New aspects of international private transactions may arise as to which federal control is desirable, and yet which do not fall within any of these powers because the other nation is unwilling to negotiate a treaty with us and the matter concerns neither admiralty nor foreign commerce. The adjustment of private international law relations with totalitarian governments, for example, is a matter for the future. ${ }^{61}$

\section{Federal Common Law}

For nearly one hundred years after Swift $v$. Tyson, ${ }^{\mathbf{6 2}}$ the bar knew that a case which came into the federal courts because of diversity of citizenship or otherwise might be governed by a common law different from the law applied in the state courts. Indeed, through the use of this federal law, the difficult problem of choice of law might at times be avoided entirely in a conflict of laws transaction. Swift $v$. Tyson itself involved a typical conflict of laws situation. A bill of exchange, dated and drawn in Maine, had been accepted in New York and then transferred to a third party in Maine. On the maturity of the bill the acceptor refused to pay on the ground his acceptance had been induced by fraud. When the transferee brought suit against him in a federal court in New York, the acceptor contended that the bill had been transferred for past consideration, that the nature of the consideration kept the transferee from being a holder in due course, and that the defense of fraud was good against the transferee. The internal laws of New York and of Maine, so it was assumed, differed on the decisive point, whether past consideration was value. If the case had been in a state court, it would have been necessary to determine which law governed, the law of Maine or the law of New York. This matter of choice of law, though argued by counsel for one of the parties, was deemed irrelevant by the Supreme Court; for, in the absence of a statute by New York or Maine on the point, the Court held that its own conception of the common law as to a holder in due course should be applied, and it was freed from the necessity of choosing between the conflicting laws of the two states.

The purpose of Justice Story in enunciating the doctrine of the federal common law has been well and sympathetically stated by Judge John Bassett Moore:

6r. Cf. Moses, Protection of Trade with Soviet Russia by Treaty-Germany's Experience, 20 AMER. BAR Ass'N J. 207 (1934).

62. I6 Pet. I (U. S. I842). 
". . . there are subjects in respect of which, in spite the fact that national legislation does not deal with them, the general convenience calls loudly for uniformity. This is particularly the case in regard to the law relating to commercial matters. For this reason, I confess I have always considered the conception of the Supreme Court of the United States in Swift $v$. Tyson as essentially sound.

". . . We may find in the decision of the Supreme Court a response to the desire which has manifested itself in all times and in all lands, and which has in so many countries led to the establishment, in one way or another, of a uniform civil and commercial law." 63

The dream of a uniform common law, to be achieved under the leadership of the Supreme Court, failed through the stubborn disregard of that leadership by the state courts. ${ }^{64}$ In Erie R. R. v. Tompkins, ${ }^{65}$ the dream was shattered. So, a transaction like Swift $v$. Tyson, if it now arose in the federal court, would present to that court, too, a choice of law.

Many commentators have discussed-what, if anything, is left of the federal common law after Erie R. R. v. Tompkins? It is clear something is left. On the very day that case was handed down, the Supreme Court decided a controversy between two states over the waters of a river; and, as if to make clear to the bar that a federal common law remains in some fields, Justice Brandeis said:

“. . . whether the water of an interstate stream must be apportioned between the two States is a question of 'federal common law' upon which neither the statutes nor the decisions of either State can be conclusive". ${ }^{66}$

The limited portion of the problem to be considered here is: In a Conflict of Laws case involving the choice of law, is the doctrine of the federal common law still alive?

It has been persuasively stated ${ }^{67}$ that the use by a federal court of its own rules of Conflict of Laws will produce the very diversity or uncertainty of treatment which it was the purpose of Erie R. R. $v$. Tompkins to end. There are substantial reasons, however, for permitting the federal courts to apply their own choice of law rules instead

63. Moore, The Passion for Unifornity (I9I4) 62 U. of PA. L. REv. 525, 539-40.

64. Frankfurter, Distribution of Judicial Power between United States and State Courts (1927) $1_{3}$ CORN. L. Q. $499,528$.

65. 304 U. S. 64 (I938), 86 U. OF PA. L. Rev. 896.

66. Hinderlider v. La Plata Co., 304 U. S. 92, I10 (1938).

67. Sampson v. Channell, Ioo F. (2d) 754, 76I-62 (C. C. A. Ist, 1940). See McCormick and Hewins, The Collapse of "General" Law in the Federal Courts (1938) 33 ILl. L. Rev. 126, 138. 
of being bound by the rule of the state where the federal court happens to sit, and it has been well said:

"In weighing the interests of the two or more states concerned in a conflicts case, the federal courts may appear a natural arbiter. . . This resolution of a difficulty created by the federal system does not seem to be an inordinate exercise of federal power. Indeed, the decision of conflicts cases may provide a reason for the existence of federal courts, especially in their diversity jurisdiction." 68

A similar reason in perhaps even a stronger form is present when the choice of law involves the law of a foreign nation. For in all aspects of foreign relations, it is natural that the agency of the central government should be dominant. It would seem natural for the federal rule choosing between the law of Illinois and the law of France, or between the law of France and the law of Germany, to be binding on the state courts rather than the reverse.

The question is still an open one, for though the Supreme Court itself posed the question in one case, ${ }^{69}$ the Court has not yet answered it.

\section{State Law}

Despite the claims of International Law and the large and growing importance of federal law, it is still the law of the states which is of major concern in private interstate and international cases. Some problems on the use of statutes and of common law of the states in these cases will be indicated.

\section{State Statutes ${ }^{70}$}

Are state statutes a source of rule for Conflict of Laws cases? The question has been answered in the negative. In overruling the contention that a New York statute fixed the law governing the validity of a power of appointment, Surrogate Fowler said:

"We cannot make rules of private international law in this state by acts of our own Legislature. Such an absurd attempt must not be imputed to a statute of this state." 71

The learned Surrogate's statement of legislative incompetency in this field cannot be accepted broadly. State statutes can change Conflict of

68. Note (1939) 52 HARv. L. REv. 1002, 1007.

69. Ruhlin v. New York Life Ins. Co., 304 U. S. 202, 206 (I938).

70. For the purposes of this article, state constitutional provisions and state statutes may be treated alike.

71. In re New York Life Insurance \& Trust Co., I39 N. Y. Supp. 695, 713 (Surr. Ct. I9I3). 
Laws rules, though the limitations set by the United States Constitution and by treaties must be respected.

In parts of the field, statutes directed to the Conflict of Laws problems are common. The exercise of jurisdiction by state courts is generally determined by explicit statutes. Within the limits set by the Constitution, the states have freedom in determining what cases their courts may hear, and how the jurisdiction of the court shall be acquired and exercised. Statutes regulating these matters are universal, and most of the litigation concerning what is broadly called jurisdiction of courts is concerned with the interpretation and application of these statutes.

The enforcement of judgments is another story. As to judgments of courts of foreign nations, state statutes are almost, if not quite, nonexistent, the matter being left to the common law rules of Conflict of Laws. As to judgments of courts of sister states, the Constitution of the United States requires full faith and credit. No act of Congress yet prescribes in detail the conditions and methods of enforcement. The usual method now employed is the cumbersome one of a new suit on the judgment itself, and even this is denied unless the judgment is final. Can a state statute expand the methods or conditions of enforcement, so as to give greater or swifter protection than is now required by the Constitution and statutes of the United States? The present minimum has been often criticized. Some courts have gone beyond the Constitutional minimum. ${ }^{72}$ If a more liberal attitude toward valid judgments were embodied in a state statute, there would seem no necessary basis for condemnation. ${ }^{73}$

The problem of choice of law, as affected by state statutes, calls for more extended comment. The statutes of a state, like the commonlaw rules of a state, are for the most part formulated without regard to Conflict of Laws. The ordinary statutes and the ordinary common-law rules of a state are normally referred to and applied, however, in a Conflict of Laws case. When a transaction having contacts with states $X$ and $Y$ is sued on in state $Y$ and the $Y$ court determines the $X$ contacts are the dominant ones, the $Y$ court will refer to and use the $X$ domestic law, whether it be statute or common law. Thus, the $X$ domestic statute may be applied in the case, though not itself directed to the Conflict of Laws situation.

These ordinary statutes are frequently or even usually phrased in language which, taken literally, is general and unlimited in scope of application. Does this general language cause the statute to apply of

72. As to alimony decrees, see Jacobs, The Enforcement of Foreign Decrees for Alimony (I939) 6 LAW \& CoNTEMP. ProB. 250, 263-264, 269-27I.

73. But see Rohden v. Rohden, IIg Misc. 624 , 198 N. Y. Supp. I6 (Sup. Ct. I922) 
its own force to all cases in the courts of the state? This question arose in the distribution of the estate of Enrico Caruso, under a statute of distribution of New Jersey which read:

"The whole surplusage of the goods, chattels, and personal estate of which any person shall die intestate shall be distributed in manner following . . . "74

The statute then provided that if the intestate left a widow and a child, one-third should go to the widow and two-thirds to the child. Caruso had died leaving a widow, a legitimate daughter, a brother, and two natural sons whom he had recognized. At his death intestate he was domiciled in Italy, and under the Italian law embodied in a court decree the daughter was awarded only one-half of his estate and each of the other indicated persons was given an eighth. Among the assets left by Caruso were royalties from the Victor Talking Machine Co., a New Jersey corporation with its principal place of business in that state. When the distribution of these assets came before the New Jersey court, the chancellor ignored the Italian law and decree and ordered the royalties distributed in accordance with the New Jersey statute. ${ }^{75}$ The Italian court, on learning its law and decree had been ignored, threatened reprisals by denying efficacy to the decree as protection to the Victor Company; but the New Jersey chancellor stood firm, saying:

"There is a positive law of this state operating upon the property which is found here, namely, the statute of distribution, the latest enactment of which is to be found in P. L. I9I8, P. I80. . . "76

The Court of Errors and Appeals ended the controversy by reversing the chancellor on the ground the scope of operation of the statute of distributions was to be determined, not by reading the statute literally, but in accordance with the recognized legal rule that the law of the domicile of one dying intestate governs the distribution of his or her personal property.

"It is to be borne in mind, that the statute of distribution is limited solely to the distribution of personal property of a person dying intestate, his or her domicile being in this state, at the time of decease." 77

The decision of the Court of Errors and Appeals is unquestionably right. Most statutes are formulated with regard to only the ordinary or internal situations and on the problems of Conflict of Laws they are

74. N. J. Laws I918, c. $63, \S 69$ (Italics added).

75. Caruso v. Caruso, I02 N. J. Eq. 393, I4I Atl. I6 (1928).

76. Caruso v. Caruso, I03 N. J. Eq. 487, 493, I43 Atl. 77I, 773 (I928).

77. Caruso v. Caruso, 106 N. J. Eq. 130, I46, 148 At1. 882, 889 (1929). 
silent. Their sphere of application or use is to be determined through the principles of Conflict of Laws. ${ }^{78}$

Granting the usual statute is of this type, there seems to be no reason why a statute may not be directed to the choice of law problem. Conflict of Laws rules carry no immunity to change, and within the limits set by the Federal Constitution a legislature of a state can control the courts of the state. There are numerous statutes of this character. Among them are the Uniform Wills Act, Foreign Executed, and the Uniform Stock Transfer Act.

The form which these statutes take varies widely. It may be a declaration that if a transaction having certain designated contacts with the forum satisfies the domestic law of the forum, or if a transaction having designated contacts with a foreign state satisfies the domestic law of that state, the transaction shall be deemed valid. For example:

"A last will and testament, executed without this state in the mode prescribed by the law, either of the place where executed or of the testator's domicile, shall be deemed to be legally executed, and shall be of the same force and effect as if executed in the mode prescribed by the laws of this state, provided, said last will and testament is in writing and subscribed by the testator." 79

Occasionally the legislature seeks to bring a transaction within the orbit of regulation by giving a special definition of a Conflict of Laws term, as, "place of making", or an internal law term, as "agent". Two illustrations will be given:

"All contracts of insurance on property, lives, or interests in this state shall be deemed to be made therein; and all contracts of insurance the application for which are taken within the state shall be deemed to have been made within this state and are subject to the laws thereof." 80

"Any person who solicits insurance and procures application therefor shall be held to be agent of the party issuing a policy upon such application, anything in the application or policy to the contrary notwithstanding." 81

At times the effort of the legislature to extend its control through these means has been upheld by the Supreme Court of the United States, ${ }^{82}$ and at times it has been overthrown. ${ }^{83}$

78. See also Plimpton v. Bigelow, 93 N. Y. 592 (I883); Note (1920) 29 Y ALE L. J. 329 .

79. UNIFORM Wills Act, Foreign ExECUTED, \& I.

80. N. C. CODE ANN. (Michie, I935) \$ 6287.

8I. 3 Fla. CoMp. GeN. LAws ANN. (Skillman, 1927) \$6222.

82. National Union Fire Ins. Co. v. Wauberg, 260 U. S. 7 I (I922) ; American Fire Ins. Co. v. King Lumber \& Mfg. Co., 250 U. S. 2 (I9I9). (1934).

83. Hartford Accident \& Indemnity Co. v. Delta \& Pine Land Co., 292 U. S. I43 
The discussion immediately preceding concerns the power of the legislature of a state to give the Conflict of Laws rules to the courts of the same state. A new difficulty is presented when such a statute of one state is relied on in the courts of another state as fixing the Conflict of Laws rules for the case. These statutory rules of the first state, like its common law rules, should ordinarily have no compelling effect on the courts of the second state. Whether they will be given effect depends on the doctrine of the renvoi.

\section{State Common Law}

If a Conflict of Laws case is not reached by any one of the bodies of law above discussed-International Law, Federal Law in its various manifestations, state statutes-its decision is guided by the state common-law rules of Conflict of Laws.

These state rules, it is well to emphasize, are like the other parts of the common law in three respects, each of which has at times been obscured by unguarded language of courts or commentators: ( $I$ ) the freedom of choice of the state in formulating the rules; ${ }^{84}$ (2) the binding character of previous decisions as precedents, on the courts of the state; (3) the factors which go into the making of the common-law rules. On each of the three, the language of the comments to Section 5 of the Restatement of Confict of Lazes deserves quotation:

(a) “. . . That part of the law of a state called Conflict of Laws is not forced on a state by any external power. The state has the same freedom to adopt its own rules of Conflict of Laws that it has to adopt any rules of law.

"Conflict of Laws, as adopted, becomes no less definitely a part of the law than any other branch of the state's law; and in the application of its principles the courts have no more discretion than in any other part of the law. . . ."

(b) ". . . It derives this law from the same sources used for determining all its law: from precedent, from analogy, from legal reason, and from consideration of ethical and social need.

\section{ConCLusion}

The limited purpose of this Article is to sketch the bearing, on Conflict of Laws cases of the various bodies of law considered. The full development of any one of the topics would demand an article or a volume.

84. In the state court analogy to the old situation of the federal common law, a few of the courts have unfortunately misconceived their role. For a collection of the cases see (I93I) 73 A. L. R. 897. 
For the lawyer or the judge, the common law of Conflicts is not enough. State statutes obviously are important. International Law, despite its great role in the adjustment of the political side of international relations, has only restricted application to this field. Federal law has frequent and compelling application. Here, the development of other nations may be significant.

"Now let us come to the gloss which says "If a Bolognian makes a contract at Modena, he shall be judged by the statute of Modena." " 85 This is the opening passage of the portions of the Commentary of Bartolus bearing on Conflict of Laws. When Bartolus wrote this first organized treatment of the subject, his examples were naturally drawn from cases inside Italy. For transactions between Bologna and Modena, or Perugia and Venice, were between city states with different statuta. When France took the leadership in the subject, many Conflict of Laws cases dealt with by the writers were intra-national, as Rennes and Paris cases or Bourges and Toulouse cases, for they involved a conflict of coutumes. And when German writers took up the burden, some of the transactions interesting them were inside Germany as we now know it, as, between Hamburg and Berlin, or Bremen and Stetin. Today, no one of these situations presents a Conflict of Laws case. For the political unification achieved by Italy, France and Germany has been accompanied or followed sooner or later by legal unification, a single national law throughout their continental areas.

Some years ago Professor Laski stated his agreement with Professor Dicey's view "that federalism is always a stage on the road to unification". For us this statement may be erroneous or premature. Certainly, however, in the interstate and international area dealt with in Conflict of Laws, the federal law has a large and growing place.

85. See Bartolus, Conflict of Laws (Beale's trans.) 17. 